\title{
THE CORELATIONS BETWEEN WHITE ROT (RIGIDOPORUS LIGNOSUS L.) INCIDENCE AND SOILCHARACTERS OF RUBBER ECOSYSTEM IN PENUMANGAN BARU,LAMPUNG
}

\author{
Joko Prasetyo ${ }^{1}$, Titik Nur Aeny ${ }^{1}$, and Radix Suharjo ${ }^{1}$
}

\begin{abstract}
The corelations between White Rot (Rigidoporus lignosus L.) incidence and soil characters of rubber ecosystem in Penumangan Baru, Lampung. A study was conducted to evaluate the corelation between soil characters and white rot incidence. The study was done in Penumangan Lampung from June 2007 to July 2008. Seven sites were observed on the incidence of white rot of indicator plants (cassava). Physical, chemical, and biological soil characters were correlated and regressed with white rot incidence. The results showed that there were correlation between white rot incidence and soil characters such as $\mathrm{pH} \mathrm{KCl}$, number of fungal genus (fungal diversity), $\mathrm{Ca}^{+}$, total cation, $\mathrm{CEC}$, and saturation base. Ion $\mathrm{Ca}^{+}$, total cation, saturation base correlated positively with white rot incidence, on the contrary, fungal diversity, cation exchange capacity, and $\mathrm{pH} \mathrm{KCl}$ correlated negatively with white rot incidence. Thus, efforts to increase fungal diversity, cation exchange capacity, and pH (in acidic soil) could be used as basic strategies to develope intergrated control of white rot disease.
\end{abstract}

Key words : Rigidoporus lignosus, rubber, soil character

\section{INTRODUCTION}

White rot disease (Rigidoporus lignosus L.) is very important disease in rubber plantation. The results of 1998 IRRDB disease survey that the disease is severe in Cameroon, Côte d'Ivoire, Indonesia, Malaysia, Sri Langka, and Thailand (Anonym, 2009). The disease causes economic lost not only for the lost of production but also the expensive control of the disease. The disease causes lost on production about $3-15 \%$ with the financial value about 2.1 billion rupiahs every year particularly in small holder plantation. The damage in small holder plantation occured often in the areas where stumps of rubber and primary forest trees exist, and in sandy and loose soil areas (Widjanarko, 1969; Basuki, 1981; Basuki, 1982; Situmorang \& Budiman, 1990).

The control of white root disease is rarely conducted such as in Penumangan (Figure1). This fact caused the high incidence of the disease in the area. The reasons are lack of knowledge on the disease and its control and lack of farmer's income.

Thus it is necessary to introduce control technology suitable to the social-economic condition of the farmers. In order to get the effective, cheap, and friendly control technique, many factors involved in white root progress must be understood.

In the concept of disease triangle, the progress of white rot disease is depended upon three factors: rubber (host), Rigidoporus lignosus (pathogen) (Figure 2), and environment. $R$. lignosus is a polyphage pathogen, it infects many host such as rubber, cassava, coffea, cocoa, and many other trees.

There is no resistant clone of rubber available (Holliday, 1980). Where ever rubbers are grown, they are threathen by white rot disease. The component of environment to increase white rot disease is soil. Soil characters are important to disease progress.

White rot fungi attact many plant stages, but the disease, ussually appears in young plantation. The symtomp will have appeared since two years old plants. And then after 5 or 6 years old the progress of the disease is slow but sure, and in the old plantation many rubber trees suffered from white rot disease (Semangun, 2000).

The plantation from forest or rubber sometimes will suffer more severe from white rot. Many infected root residues left in the soil become the food base of new infection. In central java, white rot diseases are

\footnotetext{
1 Department of Plant protection, Faculty of Agriculture, University of Lampung,

Jl. Prof. Sumantri Brojonegoro No 1 Bandar Lampung, 35145. Email : joko_prasetyo@unila.ac.id
} 


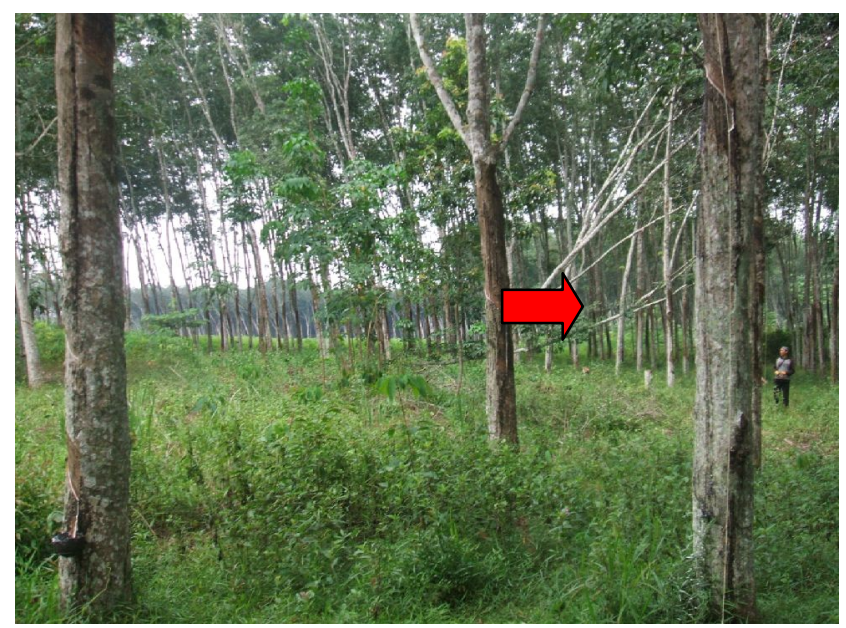

Figire 1 . The rubber tree were falling down attacked by $R$. lignosus (arrow)
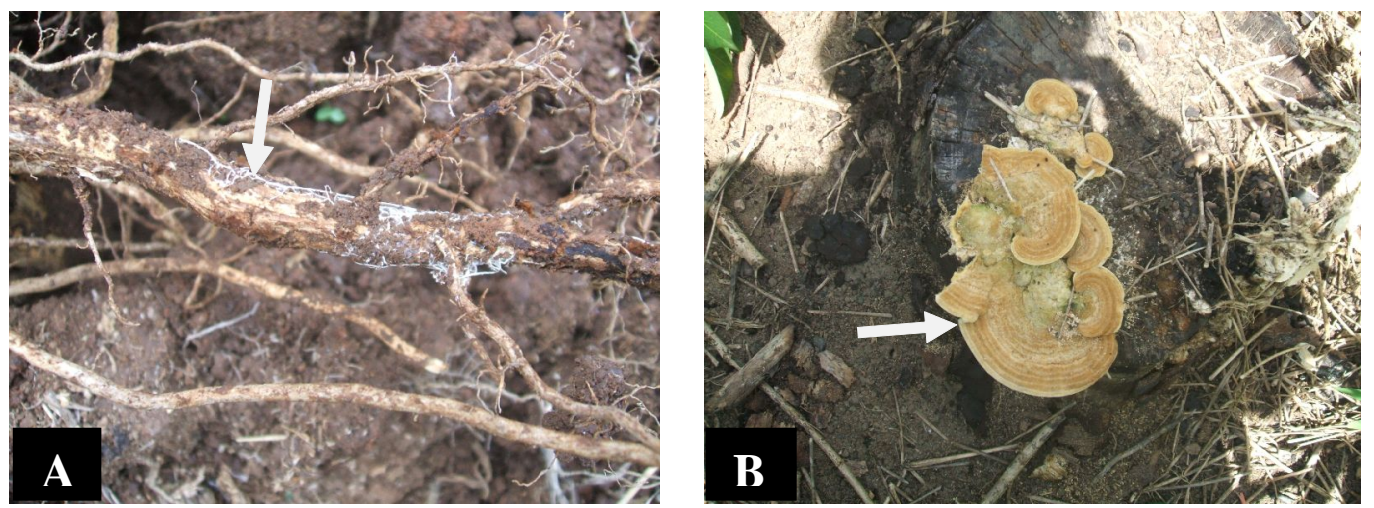

Figure 2. Rhizomorphs (A), and Basidiocarps (B) of R. lignosus

found in the plantation with the history of teak forest (Soewitooetomo, 1970). The duration of the white rot fungi in the soil is depended upon number of the infected residues in the soil and many other factors involved in the root residues decomposition. According to John (1960) on the root with diameter $0.6 ; 2.5$; and $7.5 \mathrm{~cm}$, the fungi survived in 6,20 , and 40 months respectively.

Other factors in the soil role in white root progress are $\mathrm{pH}$ and porosity of soil. White root fungi is favoured by porous soil and neutral pH (6-7) (Semangun, 2000). The disease occured in liparite soil, in East Sumatra and Southern hill of East Java. In Southern Sumatra, the disease occured in many small holder plantation, particularly in sandy soil area (Situmorang \& Budiman, 1990).

In North Sumatra, plantation with Yellow-red podzolic soil less suffer from white rot disease compared to aluvial soil. The reason is that yellow-red podzolic soil is more acid. In acid soil, the activity of laccase decrease (Bonomo et al., 2001). Laccase is an enzym belongs to polyphenoloxydase involved in lignin degradation by $R$. lignosus (Geiger et al., 1986). Other reason is that in acid soil Trichoderma koningii, antagonist of white rot fungi, is favoured (Semangun, 2000).

Indeed, many other factors involved in the dynamic of white rot, other than mention above. Thus, it is important to investigate the relationship between other soil characters and white rot incidence.

The study is conducted to evaluate the corelation between physical, chemical, and biological soil characters and white rot incidence. It is also intended to get the best combination of soil characters to suppress white rot. So, the understanding of white rot dynamics in relation to soil characters will be unraveled, and in the long run ecofriendly control of white rot disease in small holder plantation would be established. 


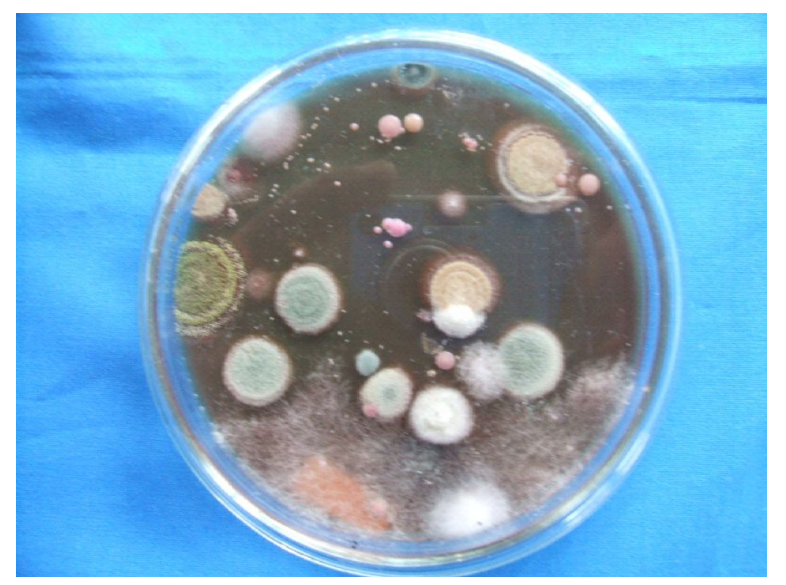

Figure 3. Dilution Plate method to identify and count number of soil fungi

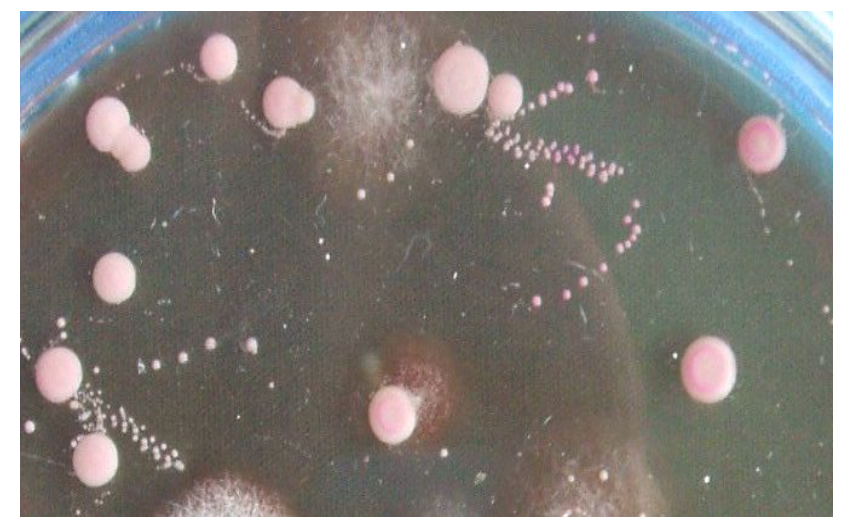

Figure 4. Bacterial colonies are growing seperately

\section{MATERIALS AND METHODS}

The observation was conducted in small holder rubber plantation in Panumangan Baru Village, Central Tulang Bawang District, Tulang Bawang regency, Lampung Province. White rot incidences were documented across seven sites in the village and the physical, chemical, and biological characters of soil in the sites were assesed.

Within each sites, soil samples were taken from nine points of the certain area diagonally and mixed together. From the mixed soil, $2 \mathrm{~kg}$ of soil is placed into two plastic bags, each bag contains $1 \mathrm{~kg}$ of soil sample. One plastic bag was sent to soil laboratory in Bogor (Bogor Soil Research Indonesia) to assess its soil characters (texture, $\mathrm{pH}$, organic matter, cation exchange capacity, etc). The other plastic bag was sent to the plant disease laboratory in the University of Lampung to assess the diversity of fungi and abudance of other soil microbes (nematode, common fungi, and bacteria).
The diversity of fungi and the abundance of the soil microbs and soil characters then be correlated with the incidence of white root rot.

Nematode Observing. Soil samples for observation of nematodes community were taken from the same point of mycorrhizal observation. From the sample points, soil sample were taken using trowel with the depth 0-20 $\mathrm{cm}$ as much as $0.5 \mathrm{~kg}$ per point and kept in polyphenyl plastic bag for the next proccess. The soil samples must be avoided from direct sunshine and must be kept in cool place before laboratory proccess.

Nematode extraction on $300 \mathrm{cc}$ of soil samples were conducted using varied level of sieving tools and then centifuse in sugar dilution (500 $\mathrm{g}$ in 11 solvent) according to Gafur \& Swibawa (2004). Laboratory proccess and the enumeration of abundance of soil nematodes is the same as explain in survey of nematode in method of plant parasitic nematode management on the cofee base agricultural land. 
Observing of Fungal diversity. Soil Samples for the observation of fungi other than white root rot fungi (Rigidoporus lignosus) were taken from the same point with nematode observation. From each point, $500 \mathrm{~g}$ soil was taken using garden trowel at $0-20 \mathrm{~cm}$ depth. Soil Samples were placed in plastic bags and kept in cool box before laboratory proccess.

The observation of fungal abundance and their diversity is conducted with plate-counting methods (Figure 3). Soil sample was diluted to get suspension series and the existing fungi were grown in rose-bengal chloramphenicol media on petridish.

The observation was conducted by grouping, counting, and identifying fungal colony with the same morphology. Identification of fungi were conducted at genus level based on fungal morphology (Von Arx, 1981, 1987; Rossman et al., 1987; Scots et al., 1994; Lane, 1997; Ellis \& Ellis, 1997; Barnett \& Hunter, 1998; CABI, 2001).
Observing of Bacteria. Bacteria in soil occur mostly in aggregates. To count the number of bacteria in soil, the soil must be diluted in a serial dilution and then plated. Identification of bacteria was done after a pure culture was obtained. From each point, $500 \mathrm{~g}$ soil was taken composited, and $100 \mathrm{~g}$ soil was diluted in $100 \mathrm{ml}$ sterile water to make $10^{-2}$. From the $10^{-2}$, aseptically transfered $1 \mathrm{ml}$ of dilution fluid to $9 \mathrm{ml}$ blank to obtain $10^{-3}$. Using a fresh, sterile pipette for each succeeding step, trasfer 1 $\mathrm{ml}$ from the $10^{-3}$ dilution to another $9 \mathrm{ml}$ blank to obtain $10^{-4}$ dilution. The similar procedure was repeated to obtain $10^{-6}$ dilution. From each dilution tube, aseptically placed $1 \mathrm{ml}$ into each of two sterile petri plates and poured $15 \mathrm{ml}$ sterile molten nutrient agar into each petri plate. Gently swirled each plate on the bench so that the inoculum thoroughly mixed with the agar. Allowed the plates to stand and solidified before inverting the plates and incubated them at room temperature for 2

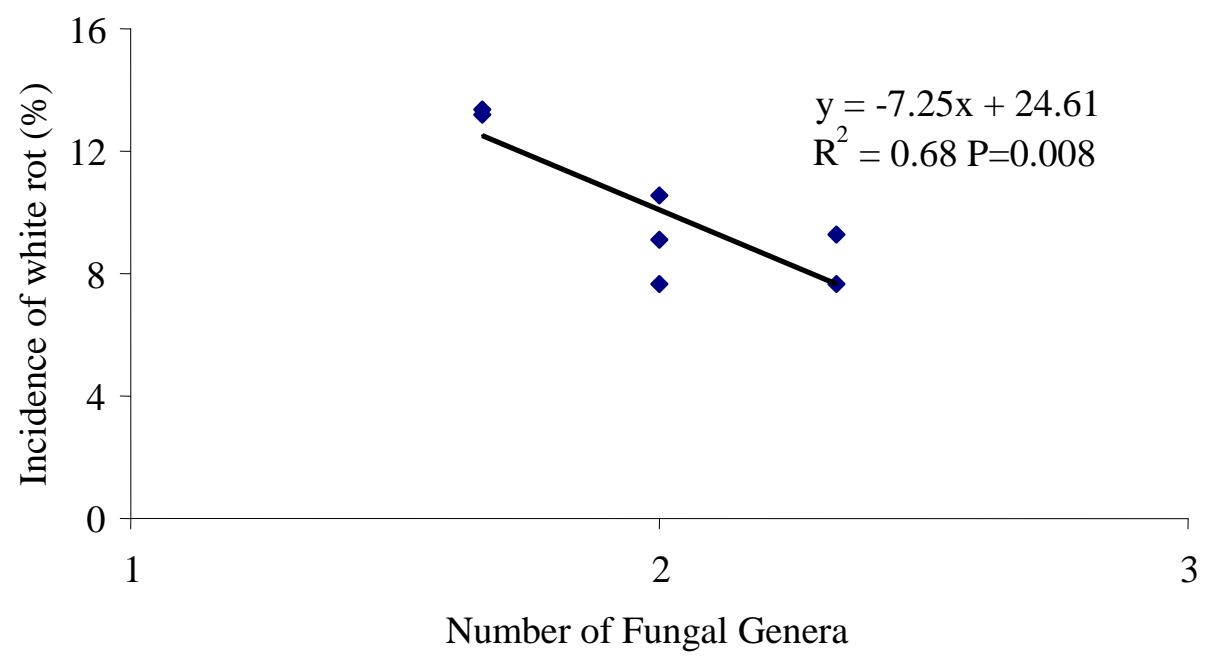

Figure 5. The relation between number of genera with white rot incidence

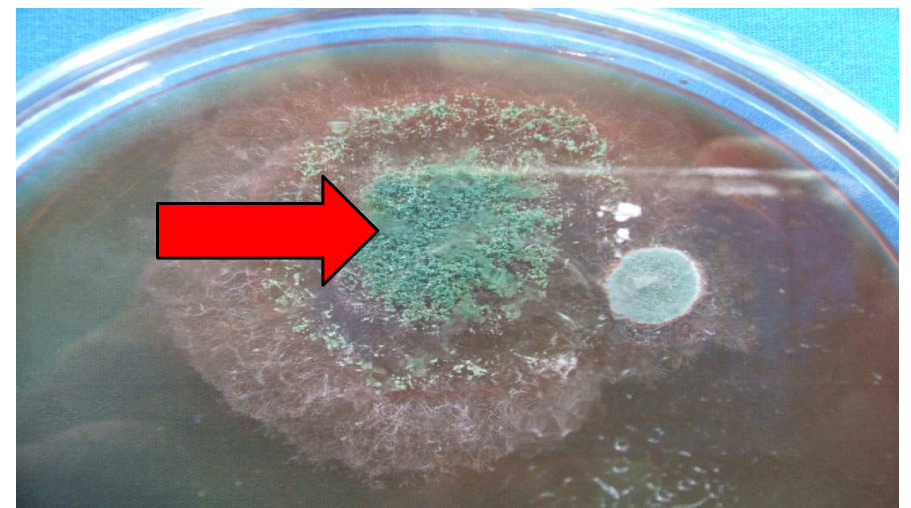

Figure 6. Colony of Trichoderma sp. (arrow) isolated from Penumangan Baru soil 
days. The number of colonies were determined from countables plates (plates from dilution that yield at least 30 colonies and less than 300 colonies, and the colony separate each other (Figure 4). Grouping of the isolated soil bacteria specimens were done based on their function grouping (antagonist, pathogen, saprophyte). Antagonist group will be noticed by the presence of clear zone around the bacterial colonies.

The pathogenicity of the bacterial isolates were determined based on HR reaction on tobacco. Further identifications up to genus level were done based on biochemical test (Fahy \& Persley, 1983).
Data Analysis. Analysis of correlation and regression were done using t-test at $\alpha=0.01$ or 0.05 level. The white rot incidences were correlated and regressed with each of the following variables: soil texture, soil organic matter, macro and micro-nutrients, CEC, base saturation, and $\mathrm{pH}$.

\section{RESULTS AND DISCCUSSIONS}

The results of the study showed that there were correlation between white rot incidence and soil characters such as fungal diversity, $\mathrm{Ca}$, total cations,

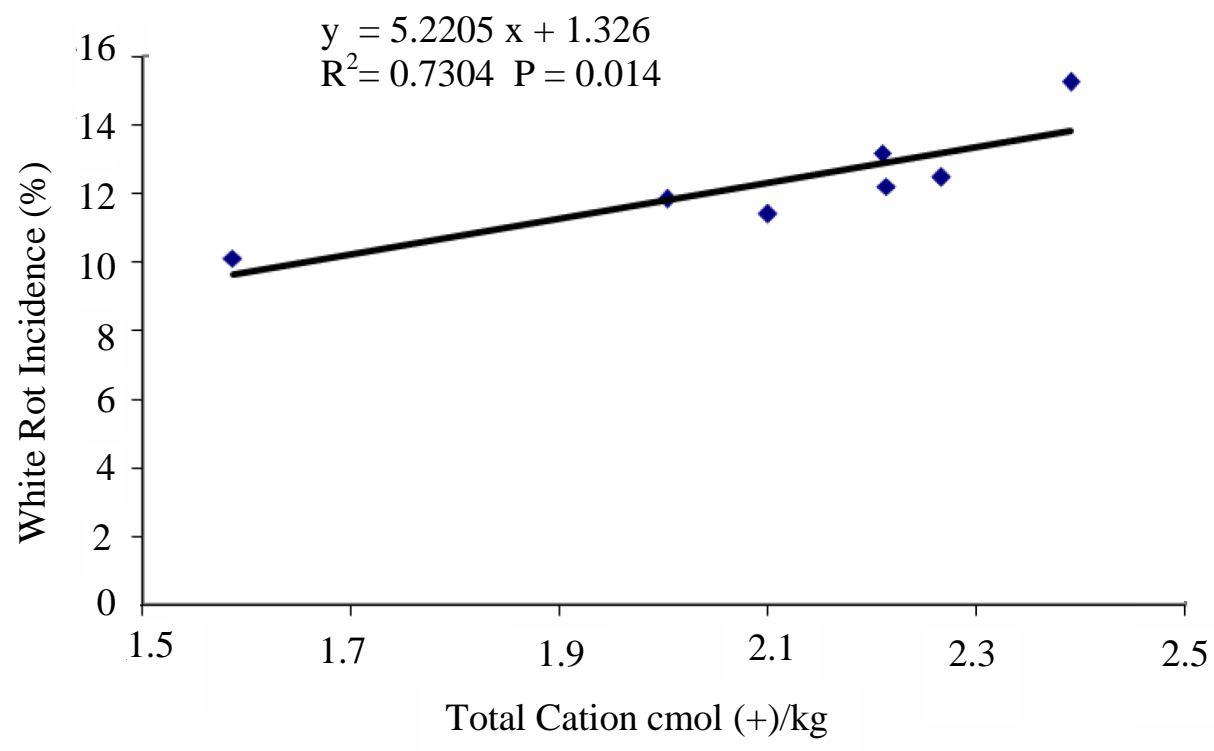

Figure 7. The relation between total cation of soil with white rot incidence

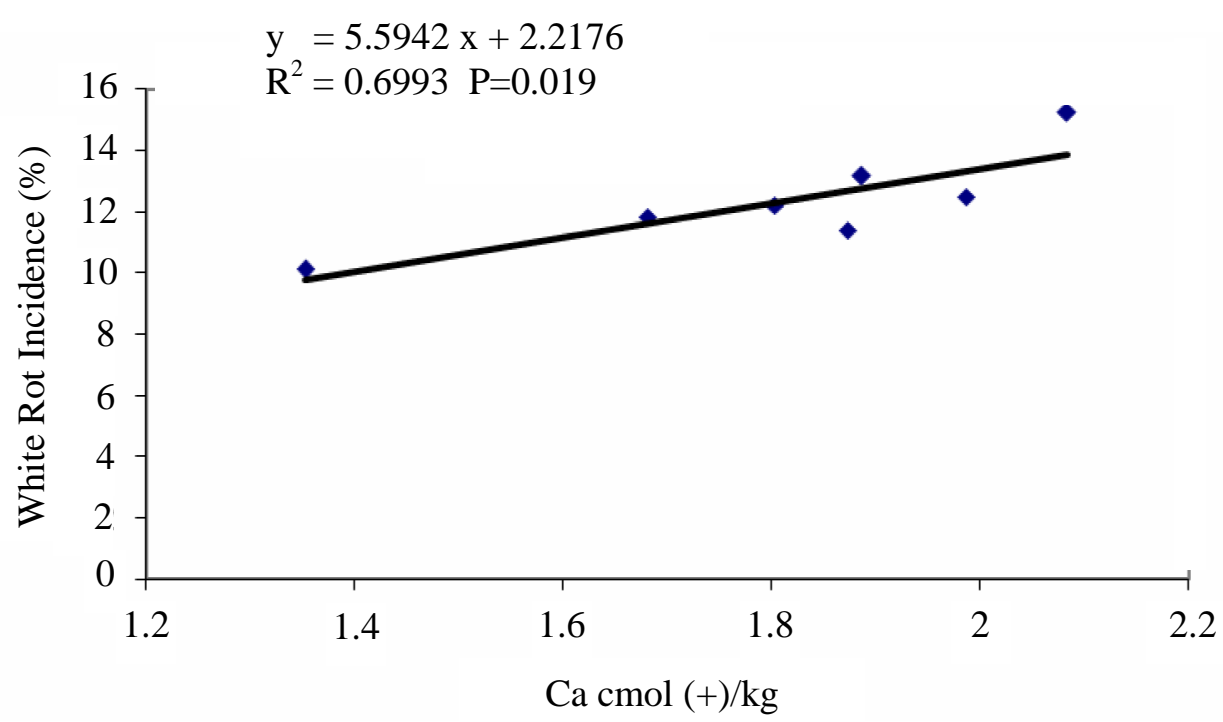

Figure 8. Relation between Ca content of soil and white rot incidence 
CEC, saturation base, and $\mathrm{pH}$ of the soil. The correlation occured at $\mathrm{P}<0.05$. There was no correlation between the diversity and abundance of nematode and bacteria investigated with white rot incidence.

There was a negative correlation between white rot incidence and fungal diversity of the soil. Soil in Penumangan belongs to acid and sandy soil. In this soil, in fact, the higher the fungal diversity of the soil the lower the white rot incidence (Figure 5). It was indicated significantly the presence of many fungal genera among them were antagonistic fungi such as Trichoderma sp. (Figure 6). The role of Trichoderma spp. in acid soil were reported by Pegg (1977). Jayasuriya \& Thenakoon (2007) found Trichoderma isolates from rubber growing area were antagonistic to $R$. lignosus.
On the contrary, there was a positive correlation between incidence of white rot and the $\mathrm{Ca}$, total cation, and saturation base of the soil in Penumangan Baru. When total cation was higher, the white rot incidence significantly to be higher (Figure 7).

The relation between total cation and white rot incidence mainly was determined by the relation between $\mathrm{Ca}$ and white rot incidence (Figure 8).

The increase of $\mathrm{Ca}$ content also increased white rot incidence. It was due to the decrease of fungal population, including antagonist of $R$. lignosus (Figure 9).

In a line with $\mathrm{Ca}$ and total cation, saturation base was also positively correlated with white rot incidence (Figure 10). It indicated that the higher the saturation base of the soil, the higher the incidence of white rot. It

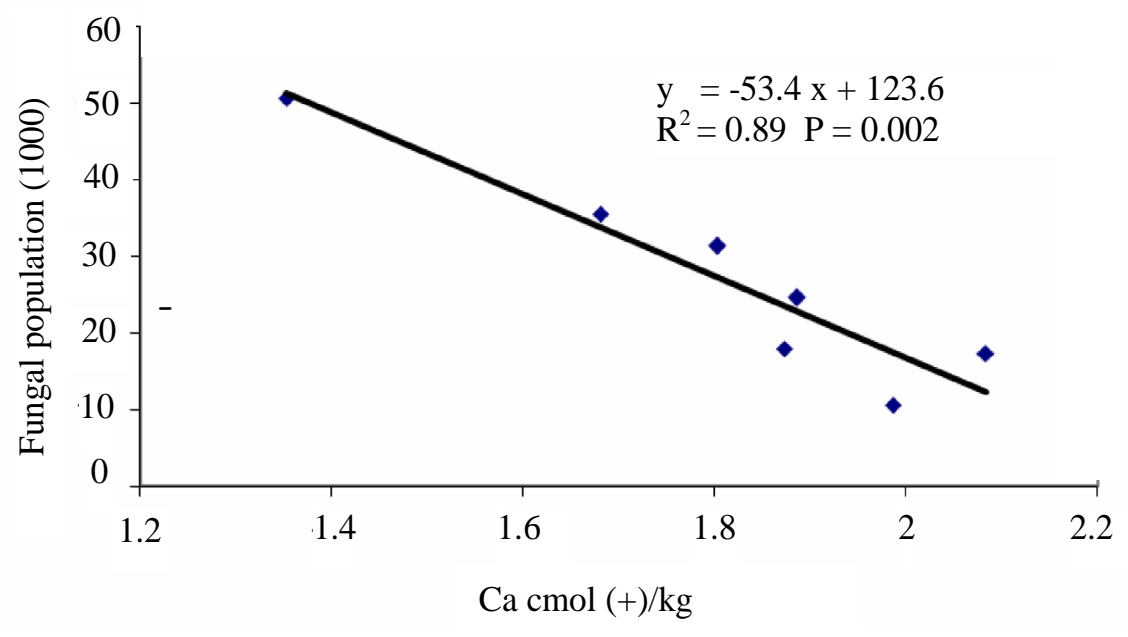

Figure 9. Relation between Ca content of soil and fungal population

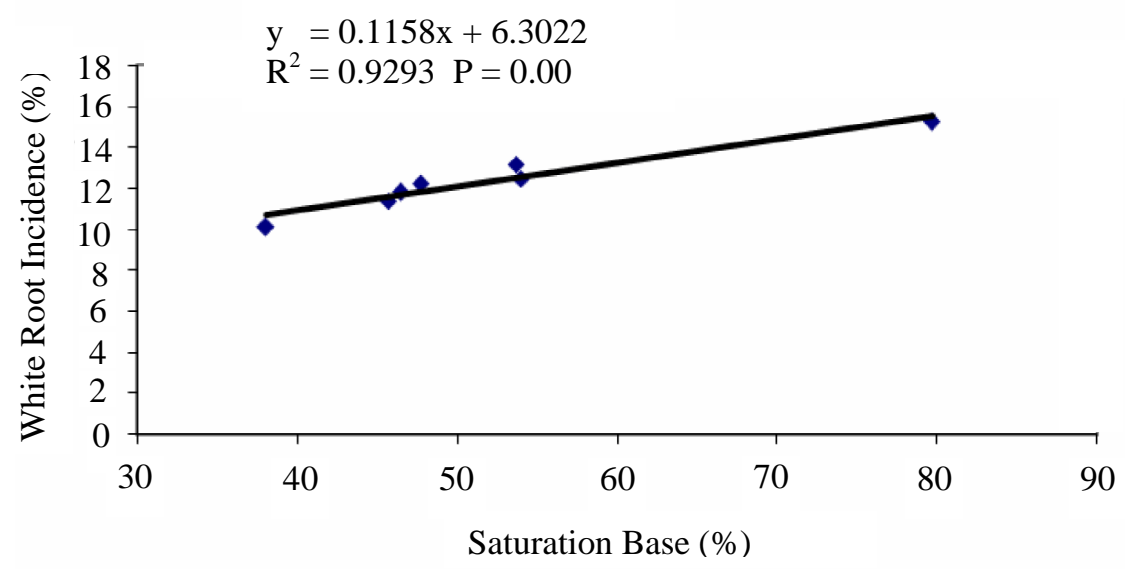

Figure10. The relation between saturation base of soil and white rot incidence 


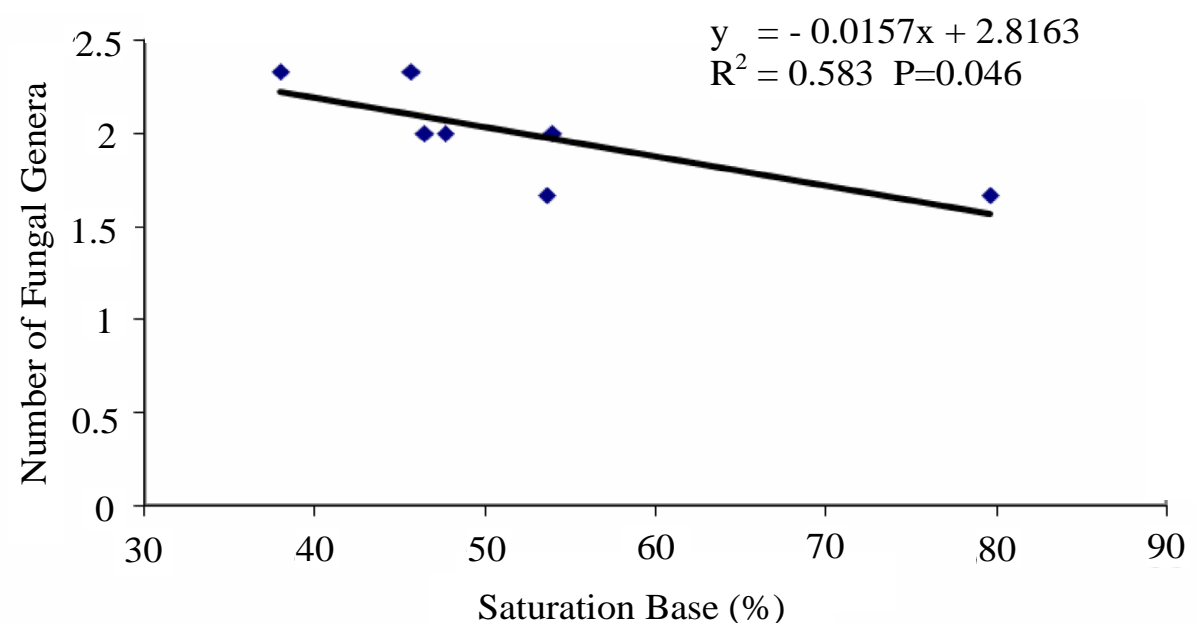

Figure 11. The relation between saturation base and fungal diversity

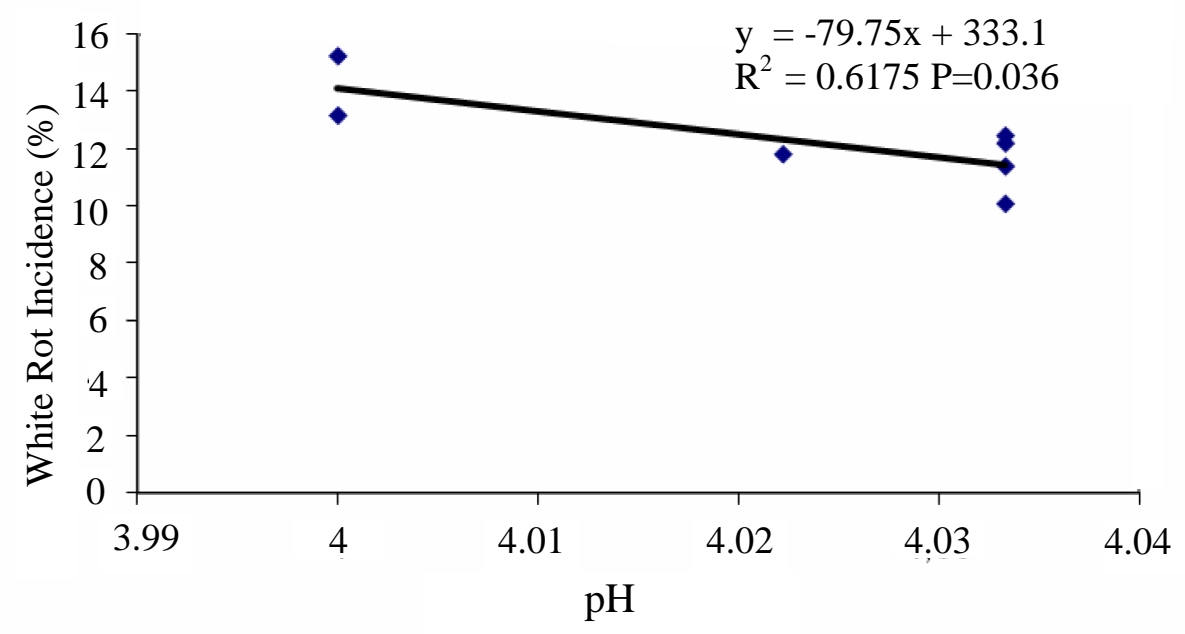

Figure 12. The relation between $\mathrm{pH}$ of soil and white rot incidence

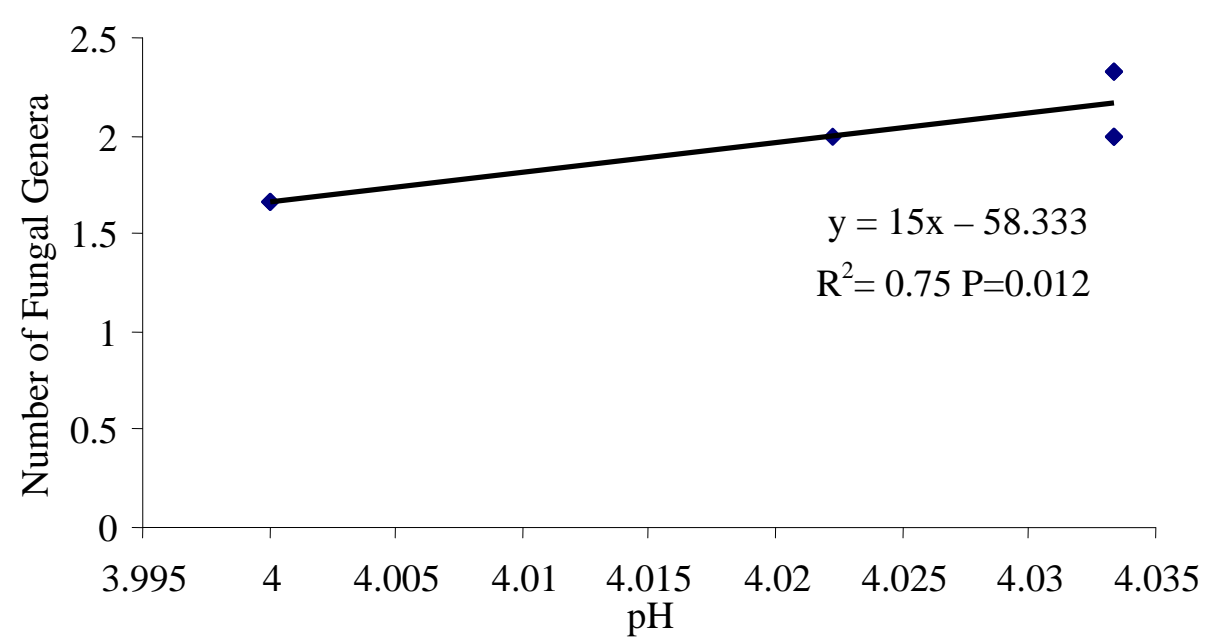

Figure 13. The relation between soil $\mathrm{pH}$ and fungal diversity 
was due to the availability of condition nearer to neutral $\mathrm{pH}$ in the soil. The $R$. lignosus needed neutral condition for activity.

Other reason is that increase in base saturation decrease fungal diversity (Figure 11), including the diversity of antagonistic fungi and finally increasing white rot fungi.

It was sureprice that $\mathrm{pH}$ of soil correlated negatively with incidence of white rot (Figure 12). In the common sense the disease is favoured by neutral pH (Situmorang \& Budiman, 1990; Semangun, 2000). It is suspected that in more acidic soil, as in Penumangan Baru (pH 4.0-4.03), the activity of $R$. lignosus is slow down for the activity laccase decreases for destabilization (Bonomo et al., 2001). So the decrease of white rot incidence as a result of the increase of soil $\mathrm{pH}$ is a new phenomena. May be, It was due to the presence of $R$. lignosus antagonist.

It is alledged that the antagonist from other fungi as supported by the fact that the increase of soil $\mathrm{pH}$ would be followed by the increase of fungal diversity (Figure 13).

Cation exchange capacity (CEC) correlated negatively with white rot incidence. The higher CEC value the lower the white rot incidence. It was due to the availability cations for the indicator plants (cassava) and finally increase the resistance of indicator plants against $R$. lignosus.

\section{CONCLUSION}

There were correlation between white rot incidence and soil characters such as $\mathrm{pH} \mathrm{KCl}$, fungal diversity, total content of calcium, total cation, CEC, and saturation base. Calcium, total cation, saturation base correlated positively with white rot incidence, on the contrary, fungal diversity, cation exchange capacity, and $\mathrm{pH} \mathrm{KCl}$ correlated negatively with white rot incidence. Any efforts to increase fungal diversity, cation exchange capacity, and $\mathrm{pH}$ (in acidic soil, $\mathrm{pH} 4.0-4.03$ ) could be used as basic strategies to develope intergrated control of white rot disease.

\section{ACKNOWLEDGEMENT}

We would like to thank to Bellow Ground Biodiversity Project for funding this research. We also thank to Dr. F.X. Susilo as chief of BGBD researcher and his support to our team. Appreciation goes to Mr. Gede Swibawa for his assistance in analysing the data. Appreciation also goes to Chandra Purnama, Mutaqin, Ari Fernando, Fitrina Sari, Marziana, Hanifah Muslimah, and Pipit for their technical assistance in the laboratory and the field.

\section{REFERENCES}

Anonym. 2009. Rigidoporus lignosus (Imazeki) Klotzsch. http://www.irrdb.com/IRRDB/ NaturalRubber/Disease/Rigidoporus.htm accessed on 2009 August 6.

Basuki. 1981. Penyakit Akar Putih. Berk. Penel. PPPP. Tanjung Morawa 8 : 18-33.

Basuki. 1982. Penyakit dan Gangguan pada Tanaman Karet. Pus. Penel. Pengemb. Perkeb. Tanjung Morawa.

Barnett, H.L. \& B.B. Hunter. 1998. Illustrated Genera of Imperfect Fungi. 4th Ed. APS Press. St. Paul, Minn.

Bonomo, R.P., G. Cennamo, R. Purrello, A.M. Santoro, \& R. Zappala. 2001. Comparation of three fungal laccases from Rigidoporus lignosus and Pleorotus ostreatus : correlation between conformation changes and catalytic activity. (Abstract). J. Inorg. Biochem. 83 (1): 67-75.

CABI. 2001. Description of Fungi and Bacteria. CABI, Wallingford, U.K.

Ellis, M.B. \& J. P. Ellis. 1997. Microfungi on Land and Plants. $2^{\text {nd }}$ edn. Richmond Publishing, Slough, UK. 
Fahy, P.C. \& G. J. Persley. 1983. Plant Bacterial Diseases: A Diagnostic Guide. Academic Press, New York.

Gafur, A. \& I. G. Swibawa. 2004. Methods in nematodes and soil microbe research for belowground biodiversity assessment. In F.X Susilo, A. Gafur, M. Utomo, R. Evizal, S. Murwani, \& I G. Swibawa (eds.), Conservation and sustainable management below-ground biodiversity in Indonesia, Universitas Lampung. pp. 117-123.

Geiger, J.P., B. Huguenia, M. Nicole, D. Nandris, \& B. Rio. 1986. Laccases of Rigidoporus lignosus and Phellinus noxius II. Effect of R. lignosus laccases L1 on thioglycolic lignin of Hevea. Appl. Biochem. Biotchnol. 13 : 97-110.

Holliday, P. 1980. Fungus Diseases of Tropical Crops. Cambridge Univ. Press. Cambridge.

John, K.P. 1960. Loss of viability of tree root parasites in infected root sections buried in soil. J.Rubb. Res. Inst. Mal. 16 : 173-177.

Jayasuriya, K.E. \& B.I. Thenakoon. 2007. Biological control of Rigidoporus microporus, the cause of white root disease in rubber. Cey. J. Sci. (Bio. Ci.) 36 (1): 9-16.

Lane, C.R. 1997. Image Analysis and archiving as an aid to fungal identification. pp: 321-323, in Diagnosis and Identification of Plant Pathogens, H.W. Dehne, G. Adam, M. Diekmann, J. Frahm, A. Mauler Machnik, \& P. Van Halteren (Eds.). Proc. Of the 4th Symp. Of the European Foundation for Plant Pathology, September 9-12, 1996, Bonn, Germany.
Pegg, K.G. 1977. Soil application of elemental sulphur as acontrol of Phytophthora cinnamomi root and heart rot of pineapple. Austral. Jour. Exp. Agric. Anim. Husb. 17 : 859-865.

Rossman, A.Y., M. E. Palm, \& L. J. Spielman. 1987. A Literature Guide to the Identification of Plant Pathogenic Fungi. APS Press, St. Paul, Minn., USA.

Scots, A., F. M. Dewey, \& R. Oliver. 1994. Modern Assays for Plant Pathogenic Fungi. CABI, Wallingford, UK.

Semangun, H. 2000. Penyakit-penyakit Tanaman Perkebunan di Indonesia. Gadjah Mada Univ. Press. Yogyakarta.

Situmorang, A. \& A. Budiman. 1990. Beberapa Metode Aplikasi Fungisida dalam Pengendalian Penyakit Akar Putih (Rigidoporus microporus) pada Tanaman Karet. Pros. Konf. Nas. Karet. Palembang. Buku II: 383-394.

Soewitooetomo, S. 1970. Masalah Penyakit Cendawan Akar Putih (Fomes lignosus) pada Perkebunan Karet Di Jawa Tengah. Kongr. Nas. I PFI. Pagilaran, Pekalongan, Agustus 1970.

Von Arx, J.A. 1981. The Genera of Fungi Sporulating in Pure Culture. 3rd edn. J. Cramer, Vaduz.

Von Arx, J.A. 1987. Plant Pathogenic Fungi. J. Cramer, Berlin and Stuttgart, Germany.

Widjanarko, S. 1969. Pemberantasan tjendawan akar putih pada karet remadja. Siaran Kilat No. 1 BPP Bogor. Seri Crop Protection. 